\title{
Correction to: How does size affect capital expenditures? Evidence from Borsa Istanbul
}

\section{Gökberk Can $^{1}$ (D) $\cdot$ Samet Günay ${ }^{1} \cdot$ Murat Ocak $^{2}$}

Published online: 25 January 2022

(c) Springer Nature Switzerland AG 2022

\section{Correction to: SN Bus Econ (2021) 1:21 \\ https://doi.org/10.1007/s43546-020-00021-w}

Unfortunately, Tables 11 and 12 contain mistakes.

In Table 11, the second row of each variable has a negative sign which must be replaced with brackets "()".

In Table 12, the second row of each variable has brackets "()" missing.

The original article has been corrected.

Publisher's Note Springer Nature remains neutral with regard to jurisdictional claims in published maps and institutional affiliations.

The original article can be found online at https://doi.org/10.1007/s43546-020-00021-w.

Gökberk Can

gc@gokberkcan.com

1 College of Business Administration, American University of the Middle East, Egalia, Kuwait

2 Uzunkopru School of Applied Sciences, Trakya University, Edirne, Turkey 